\title{
Incentives +
}

\section{How can REDD improve well-being in forest communities?}

\section{Eva Wollenberg ${ }^{1}$ and Oliver Springate-Baginski ${ }^{2}$}

\section{Key points}

- REDD initiatives are more likely to succeed if they build on the interests of forest communities and indigenous people.

- More attention is needed to the balance of incentives, benefits, rights and political participation across levels of decision making, interest groups and administration.

- Incentives can include payments or other benefits for good practices, developing alternative livelihoods, formalising land tenure and local resource rights and intensifying productivity on nonforest lands.

- The pressure to reduce deforestation needs to be spread across many levels to reduce the burden on forest communities.

\section{Introduction}

Initiatives to reduce emissions from deforestation and degradation (REDD) will directly affect the 1 to 1.6 billion people who depend on forests and who are among the world's poorest. REDD mechanisms are more likely to succeed if they build on (rather than conflict with) the interests of local communities and indigenous groups. REDD also offers a critical opportunity to enhance forest communities' wellbeing, a principle upheld by several international agreements and widely accepted voluntary standards related to REDD (box 1).
This Infobrief discusses how REDD can be designed to benefit local people while also reducing emissions. Lessons are drawn from incentive-based approaches to forest conservation and recent experiences in six countries (Brazil, Indonesia, Madagascar, Mexico, Tanzania and Nepal). ${ }^{3}$ The findings suggest that the success of REDD and its impacts on communities will depend on the linkages between incentives and long-term development opportunities, resource rights and political participation for marginalised forest communities, as well as their distribution across different levels (community, district, nation) and entities (communities, timber industry, local government).

\section{Incentive strategies}

Providing compensation for lost livelihood opportunities will at best only reproduce poverty. Hence REDD should give priority to incentives that enable win-win approaches to reducing deforestation while also alleviating poverty wherever possible (See Peskett et al. 2008). Ample experience with these approaches exists in programmes that have used payments for environmental services (PES) (Engel et al. 2008; Grieg-Gran et al. 2005), voluntary carbon markets or 'carbon forestry' (Corbera and Brown 2008), the clean development mechanism (CDM) (Paulsson 2009), integrated conservation and development programmes (Wells and Shane 2004), and community forestry. Incentives should directly link outcomes associated with well-being to forest conservation (Salafsky and Wollenberg 2000). They should also support alternatives that are lower in emissions to avoid 'sectoral leakage' (a shift of emissions from forestry to another sector) and support a structural transition to a low-carbon economy. 


\section{Box 1. Excerpts from international standards and principles that protect the well-being of forest communities}

The peoples concerned shall have the right to decide their own priorities for the process of development.

- Article 7, International Labour Organisation Convention 169 for Indigenous and Tribal Peoples

The project must generate net positive impacts on the social and economic well-being of communities and ensure that costs and benefits are equitably shared among community members and constituent groups during the project lifetime.

- Climate, Community and Biodiversity Alliance Standard CM1, December 2008

Indigenous peoples have the right to own, use, develop and control the lands, territories and resources that they possess by reason of traditional ownership or other traditional occupation or use.

- Article 26, United Nations Declaration on the Rights of Indigenous Peoples

The benefits associated with incentives take diverse forms. Key strategies include:

\section{- Performance - based exchange payments} or other benefits for carbon sequestration, good forest and land stewardship, conservation targets, sustainable forest management (including fire protection) and forest restoration. Benefits include - compensation for opportunity costs, transaction costs, implementation costs or other disincentives;

- transition payments, such as resettlement funds; - increased range of livelihood opportunities; and - public infrastructure such as health, education or roads or access to assets such as land that can yield further benefits into the future.

- Alternative livelihood options and sources for forest products that reduce pressure on forests. This includes shifting agriculture away from forest land, resettlement, restructuring local economies, shifting to substitutes for natural forest products (such as woodfuel from woodlots), transition support payments ${ }^{4}$ and training.

- Enhanced security of tenure through formal legal acknowledgement of local resource rights and sharing of benefits from forests, forest land or forest products. This is based on the assumption that people will protect and invest in the forest if they can benefit later from the results.

- Increased land use efficiency to intensify productivity on nonforest lands and reduce pressure for use of forest lands, although any land use with high returns is at risk of expansion into forest areas.

Translating incentives into improved well-being and long-term development opportunities, however, requires more than providing benefits linked to reduced emissions. The following sections explain how incentive programmes can be structured to best benefit local forest communities.

\section{Distribution of benefits across multiple scales and levels}

REDD will need to provide incentives that address drivers of deforestation at multiple scales (Karsenty 2008, Ribot forthcoming). Focusing only on local incentives is like trying to stop a river flowing through a series of dams by only closing the last dam. Even partially closing an upstream dam reduces the pressure on the final dam.

By spreading the pressure for reducing deforestation across multiple parties, local people will bear less of the burden and will have more options to meet their needs. This approach also spreads the risk of failure of any one incentive. A group of incentives in Indonesia might include, for example:

- Incentives for timber harvesters to practice reducedimpact logging;

- Incentives to redirect planned agricultural development or estate crops to degraded lands;

- Livelihood enhancement programmes (such as building on integrated conservation and development experiences) to reduce encroachment and illegal logging;

- Environmental service-type payments for entrepreneurial measures that increase carbon sequestration.

Using three types of compensation, Brazil has developed a useful model for balancing benefits among states with different levels of deforestation or conservation practices - such as between Mato Grosso, with historically high deforestation rates, and Amazonas, with low deforestation rates and high forest conservation (Stella et al. 2009). The compensation types are: 
1. The opportunity cost related to deforestation reduction, as calculated by Instituto de Pesquisa Ambiental na Amazônia (IPAM) and Woods Hole Research Center (Nepstad et al. 2007).

2. Compensation for forest conservation based on an estimated cost for the management of protected areas in the Amazon.

3. Compensation to states that demonstrate achievement of deforestation reduction targets.

Brazil has adopted other models for distributing benefits at the local level. In the Bolsa Floresta programme, for example, local benefit schemes include monthly payments to families as well as regular income to the community and grants to various social organisations (Box 2).

Indonesia has developed a model for distributing REDD benefits based on forest permits (Table 1) in their REDD policy produced in 2009 (Ministry of Forestry Regulation 36 on the implementation procedures for REDD). By sharing benefits, government, community groups and project developers can each receive payments. Yet many communities are unaware of these permits, and some have not applied for customary status.
The process for allocating customary rights has been slow and uneven. For this initiative to be successful awareness building and institutional support are needed.

Mexico is using spatial analysis to assist in implementing REDD (Corbera and Estrada 2009). Maps will be produced that show areas threatened by imminent deforestation; overlays will show the incentives required (based on opportunity costs), levels of social marginalisation and community organisation. The analysis will be useful for determining how to distribute incentives geographically.

\section{Links to long-term development}

To support long-term development, REDD incentives should link to well-established pathways out of poverty, ensure the participation of the poor and build in safeguards against risks such as capture of benefits by elite groups. Experience suggests that none of these measures is straightforward, however. Ongoing monitoring, problem solving and sharing of learning will be needed. The following key questions provide a framework for this learning process:

\section{Box 2. Bolsa Floresta Program, State of Amazonas, Brazil}

The Amazonas Sustainable Foundation (Fundação Amazonas Sustantável) is responsible for implementing the Bolsa Floresta Program, which values and compensates traditional populations and indigenous people - the forest guardians - for their roles in conservation. It is the first Brazilian programme to pay for environmental efforts performed by Amazonian communities. It aims to reduce greenhouse gas emissions caused by deforestation and improve human subsistence. The challenge is to make forests more valuable standing than cut. In June 2009, the programme had reached 14 protected areas, and 6050 families were registered in it. There are four types of association with the programme:

Family. Each family receives a monthly payment of $\mathrm{R} \$ 50$, about US\$29. This income aims to supplement the families' expenses in the form of an environmental service payment.

Association. All communities living in areas under conservation are represented by family associations. These are eligible for grants amounting to $10 \%$ of the total payment made to individual associated families. The payments are made directly to the association or through local commercial credit.

Social. A small grant is provided to fund local social activities or community projects. These grants complement state and local government programmes. Families are eligible for small projects ( $R \$ 4000$ per community or about US\$2300, with an average of 11.4 families per community). Activities funded by the grant must be in line with the sustainable practices monitored in the other types of Bolsa Floresta.

Income. All communities are eligible for a grant of about $\mathrm{R} \$ 4000$ to support local income-earning activities that do not produce smoke and fit legal requirements. 
Table 1. Distribution of benefits by permits in Indonesia, 2009

\begin{tabular}{lccc}
\hline Type of forest permit & $\begin{array}{c}\text { Government } \\
\text { (in \%) }\end{array}$ & $\begin{array}{c}\text { Community } \\
\text { (in \%) }\end{array}$ & $\begin{array}{c}\text { Project developer } \\
\text { (in \%) }\end{array}$ \\
\hline Use of forest timber products in natural forest & 20 & 20 & 60 \\
$\begin{array}{l}\text { Use of forest timber products in } \\
\text { plantation forest }\end{array}$ & 20 & 20 & 60 \\
$\begin{array}{l}\text { Use of forest timber products for ecosystem } \\
\text { restoration }\end{array}$ & 20 & 20 & 60 \\
$\begin{array}{l}\text { Use of forest timber products in community } \\
\text { plantation forests }\end{array}$ & 20 & 50 & 30 \\
Community-planted forest & 10 & 70 & 20 \\
Community-managed forest & 20 & 50 & 30 \\
Customary forest & 10 & 70 & 20 \\
Village forest & 20 & 50 & 30 \\
Production forest management unit & 30 & 20 & 50 \\
\hline
\end{tabular}

1. To what extent can REDD benefits provide a path out of poverty? Incentives must be linked to assets or to the building of capabilities that increase long-term well-being, as measured by standards such as the Human Development Index. Providing compensation for lost livelihood opportunities implies an exchange of equal value, potentially reproducing poverty. The impacts of payments may need to be weighted by associated risks to consider losses due to capture by elite groups, market shifts or policy changes (Malimbwi and Zahabu 2009). Locally appropriate financial networks are likely to be more successful in distributing funds to the right actors while accounting for leakage and nonpermanence (Corbera and Estrada 2009). It is also important to strengthen the capacity of local government and civil society groups to implement and adapt REDD to local circumstances.

\section{How can REDD enable the poor to}

participate? The barriers and opportunity costs of participation must be reduced for the poor, and transaction costs must be lowered for buyers of carbon so they can engage many small providers (Martin 2009). Use of aggregators or organised groups of small providers should decrease costs for buyers and sellers of carbon and improve forest communities' negotiating power (see experience of Federation of Community Forest Users, Nepal). Tanzania and Madagascar plan to build on existing government-based participatory or community forestry programmes as the building blocks of a REDD programme (Malimbwi and Zahabar 2009, Ferguson 2009).

\section{How can REDD build in safeguards to avoid} harming local communities? Forest communities must be informed and have choices. From a social justice perspective, continuity in livelihood practices, or 'breathing space', should be an option for indigenous groups, long-term residents or the very poor for whom alternative livelihoods may not exist, or where changing livelihood strategies or participating in new programmes may be too risky or unattractive. Prior and informed consent is essential to ensure this option, and the cost to participants should not exceed the benefits. Uniform programmes result in uneven net benefits, as user costs vary (Martin 2009).

\section{How can REDD overcome the problem of} elite capture of benefits? Explicit controls are needed to prevent capture of benefits by elites. PES, $\mathrm{CDM}$ and voluntary carbon forestry programmes have tended to reinforce existing power relationships, leading to disproportionate benefits for intermediaries and the elite. Weak collective action has allowed the wealthiest to accumulate benefits. Levies on certain kinds of projects, geographical quotas and voluntary standards for sustainable development would help programmes improve social equity (Brown 2009). 
5. How can REDD ensure local resource rights are strengthened and not

undermined? Rights to carbon, forest and land are central to the question of who is accountable for managing forest carbon and who should receive incentives (Robledo et al. 2008). Yet many forest communities continue to lack secure formal tenure. In Mexico, linking PES schemes to local property rights was essential for successful outcomes (Corbera et al. 2009); informal land rights holders were more likely to be marginalised from benefits than formal rights holders (Brown 2009).

Carbon forestry markets tend to lead to formalised land rights, which in turn tend to marginalise the poor and disempower customary authority structures. While clear resource rights are desirable, allowing the market to define rights or defining rights that are not widely accepted as legitimate or stable leads to undesired consequences and can foster conflict. Building clear, legitimate tenure takes time; this activity should not be rushed as part of REDD implementation schedules.

Granting entitlements to some may also affect the incentives for REDD implementation for others (Cotula and Mayers 2009). The question is what types of resource rights related to land, forest, forest products and carbon provide sufficient clarity and security for REDD implementation (and benefit distribution) to be effective and equitable, and which rights are politically possible to secure. Carbon rights are only beginning to be defined; how they are linked to existing resource rights remains unclear.

\section{What other factors are important?}

Incentives are not a panacea. They must be weighed against other influences on people's behaviour. In Mexico and Uganda, for example, people participated in PES even when benefits were low, probably due to non-income benefits and incidental environmental services (Martin 2009; Kosoy, Corbera and Brown 2008). In Madagascar, a local nongovernmental organisation and policing may have influenced forest conservation more than payments did (Ferguson 2009). Incentives may also create perverse effects by encouraging expansion of agriculture or attracting higher local populations that increase pressure on forests (Campbell 2009).

\section{Links to meaningful participation in REDD decisions by local people}

Griffiths (2009) has criticised REDD processes for 1) poor involvement of indigenous and local forest communities in negotiations and 2) lack of clear commitments in intergovernmental REDD proposals to address rights and equity issues of local people. Communities need to have a say in the design and implementation of REDD incentives, especially if national REDD policies are developed (Rights and Resources and the Rainforest Foundation Norway 2008). Having a role in decisions that affect them is a social justice issue (Lovera 2008), but it should also improve REDD's relevance.

Although national scale programmes are currently favoured for REDD, a nested approach that relies on linking local governments with national frameworks will be needed to enable representation of local interests in political processes (Angelsen 2008). Local governments will need to respond to local interests and coordinate with upper levels of administration. Nested approaches can integrate national efforts that address leakage within a country and large-scale forces for deforestation with subnational efforts that reflect locally relevant drivers of deforestation and institutional conditions. Yet local institutions have had their own challenges under PES schemes. Studies have shown they often have had higher transaction costs and more limited capacities (Corbera and Estrada 2009; Martin 2009). Under PES, outside entities did not always find it easy to observe local institutions and ensure their accountability.

\section{A framework for analysing REDD incentives}

As this discussion indicates, to make REDD work for forest communities, incentives will need to be clearly linked to drivers and benefits at multiple scales, development opportunities and participation of local communities in REDD decisions. Table 2 shows one way to analyse incentives across these multiple requirements.

The matrix is constructed by identifying relevant interest groups at different levels and scales. The incentive strategies can be analysed by looking at the extent to which they 1) share the burden for forest management beyond forest communities; 2) provide pro-poor, locally adapted incentives linked to longterm development opportunities; and 3) create safety nets and livelihood options for communities across 
Table 2. Sample matrix for analysing incentive strategies, benefit sharing and political participation

\begin{tabular}{lllll}
\hline & Households & Community & Local government & Timber industry \\
\hline $\begin{array}{l}\text { REDD incentive } \\
\text { strategy }\end{array}$ & $\begin{array}{l}\text { Payment for reduced } \\
\text { deforestation }\end{array}$ & $\begin{array}{l}\text { Increased efficiency of } \\
\text { land use }\end{array}$ & $\begin{array}{l}\text { Payment for } \\
\text { conservation targets }\end{array}$ & $\begin{array}{l}\text { Compensation for } \\
\text { shift to plantations }\end{array}$ \\
$\begin{array}{llll}\text { Type of benefit } \\
\text { Compensation for } \\
\text { income opportunities } \\
\text { foregone }\end{array}$ & $\begin{array}{l}\text { Payment in kind for } \\
\text { meeting target, e.g., } \\
\text { improving roads }\end{array}$ & $\begin{array}{l}\text { Payment for } \\
\text { managing } \\
\text { conservation }\end{array}$ & $\begin{array}{l}\text { Transition payment } \\
\text { covering transaction } \\
\text { costs }\end{array}$ \\
$\begin{array}{l}\text { Positive and } \\
\text { negative links } \\
\text { to development } \\
\text { impacts }\end{array}$ & $\begin{array}{l}\text { Income generation; loss } \\
\text { of traditional forest uses }\end{array}$ & $\begin{array}{l}\text { Investment in public } \\
\text { assets; increased } \\
\text { settlement and } \\
\text { market development }\end{array}$ & $\begin{array}{l}\text { Investment in long- } \\
\text { term ecological } \\
\text { sustainability }\end{array}$ & $\begin{array}{l}\text { New jobs created; } \\
\text { product cost } \\
\text { increased, users } \\
\text { of plantation land } \\
\text { displaced }\end{array}$ \\
$\begin{array}{l}\text { Mechanism for } \\
\text { participation in } \\
\text { decisions }\end{array}$ & $\begin{array}{l}\text { Voluntary participation; } \\
\text { informal feedback } \\
\text { to programme }\end{array}$ & $\begin{array}{l}\text { Community } \\
\text { representative in } \\
\text { implement steering } \\
\text { committee }\end{array}$ & $\begin{array}{l}\text { None; mandated } \\
\text { national programme }\end{array}$ & $\begin{array}{l}\text { Industry } \\
\text { representative on } \\
\text { advisory committee }\end{array}$ \\
\hline
\end{tabular}

multiple levels and link those levels. The table can also be used to assess equity, e.g., across different kinds of forests, including high deforestation threat areas and conserved forests; and the mix of private and public benefits, or other distributional attributes of interest.

\section{Recommendations}

Three actions are important to support local communities' livelihoods and governance:

1. Build on existing international instruments and voluntary standards and processes to establish principles for local people's involvement and wellbeing, and allocate resources in REDD to implement them. Reinforcing these principles is necessary because they remain unevenly implemented, and not all parties have signed prior agreements or adhere to voluntary standards. The key principles include:

- Free prior and informed consent (FPIC) to inform forest communities about REDD policies and rights.

- Meaningful participation of forest communities in conceptualising, designing, testing and monitoring REDD.

- Clarification and strengthening of local resource rights prior to REDD, including rights to land, non-timber forest products, forest, carbon and ecosystem services that are linked to forests. Close the gap between rights on paper and rights in practice.

- Clear legal frameworks for resolving uncertainties and disputes, including independent judicial arbitration systems.
2. Prioritise win-win approaches that reduce emissions and support long-term development opportunities for forest communities. Link REDD incentives to clear benefits, long-term low-carbon development opportunities and mechanisms for participation for indigenous and local community groups.

3. Provide incentives to reduce deforestation across multiple parties, not just local communities. This will reduce the risk of any one incentive failing and will reduce pressure on the poorest. Include groups that contribute to clearing or conserving forests.

4. Balance REDD incentives and benefits at individual, household, community and larger scales to create safeguards, ensure equity and control elite capture.

\section{Research priorities}

To achieve these actions requires further research. Priorities include:

1. The role of incentives and their links to forest communities' well-being with respect to REDD+ efficiency, effectiveness and equity (Angelsen 2008).

- What are the tradeoffs and synergies between cost-effective reduction of emissions and improvements in local well-being? Which projects have the greatest potential to provide co-benefits for local people? How are short-term and long-term goals being traded off?

- How do incentives at different levels and those targeted at different interest groups affect emissions and social equity? 
- How do land, forest and carbon rights affect REDD's effectiveness and impacts on local people?

- What kinds of institutional and governance features are desirable for REDD to meet the needs of communities and indigenous people, including participation in REDD decisions? How effective are aggregators and federations?

- Where should REDD be implemented on the landscape to be most cost effective? Carbon can range from 30-300 tons/ha. What are the REDD hotspots and how do they overlap with communities and indigenous people's values on the landscape? Human, governance and structural dimensions in hotspots need to be analysed to understand threats, alternatives and capacities. Hot spots need to be compared with current REDD demonstration sites.

2. How REDD incentives can be used to address the deeper changes required to achieve a stable future climate and economy.

- How can REDD funds be invested locally to optimise carbon landscapes? How do these landscapes address needs for energy? How will they affect forest economies?

- How can REDD funds be used to create the structural changes necessary to achieve a lowcarbon future. Can REDD include the costs of the transition to the low-carbon economy?

3. The underlying power structures and social processes affecting how REDD is designed and implemented. These may explain why benefits are not reaching the poor and support debate and reform of REDD architecture. Priority areas include:

- What factors determine what kinds of REDD projects will be established (e.g. policy processes, corporate behaviour, donors)?

- What is the political economy underlying how baselines have been set and how forests and degradation have been defined.

\section{Notes}

1. University of Vermont, Lini.wollenberg@uvm.edu

2. University of East Anglia, Oliver.Springate@uea.ac.uk

3. Workshop held 6-8 April 2009 by the University of East Anglia and CIFOR on the Effects of REDD on Local Livelihoods and Governance. This Infobrief is a synthesis of the presentations and discussion at the workshop.

4. For example, a smallholder project in Pará, Brazil, offers transition funds for agriculture near the transAmazon highway to help the area build a new regional economy.
5. Including the United Nations Declaration on the Rights of Indigenous Peoples; International Labour Organisation Convention 169 on Indigenous and Tribal Peoples; Forest Law Enforcement and Governance; Climate, Community and Biodiversity Alliance standards; and forest certification standards of the Forest Stewardship Council.

\section{References}

Angelsen, A. 2008 Moving ahead with REDD: issues, options and implications. CIFOR, Bogor, Indonesia.

Brown, K. 2009 Insights from CDM and voluntary carbon projects. See: Springate-Baginski, O. and Wollenberg, E. (eds) 2009.

Campbell, B. 2009 Beyond Copenhagen: REDD+, agriculture, adaptation strategies and poverty. Global Environmental Change 19: 397-399.

Climate, Community and Biodiversity Alliance (CCBA) 2008 Climate, community and biodiversity project design standards, $2 \mathrm{~d}$ ed. CCBA, Arlington, VA, USA December, 2008. www.climate-standards.org (5 November 2009).

Colchester, M. 2007 Making FPIC-free, prior, informed consent - work: challenges and prospects for indigenous people. Forest Peoples Program. http:// www.forestpeoples.org/documents/law_hr/bases/ fpic.shtml

Corbera, E. and Brown, K. 2008 Building institutions to trade ecosystem services: marketing forest carbon in Mexico. World Development 36(10): 1956-1979.

Corbera, E. and Estrada, M. 2009 Mexico's Forest Policy and REDD. See: Springate-Baginski, O. and Wollenberg, E. (eds) 2009.

Corbera, E., González Soberanis, C. and Brown, K. 2009 Institutional dimensions of payments for ecosystem services: an analysis of Mexico's carbon forestry programme. Ecological Economics 68: 743-761.

Cotula, L. and Mayers, J. 2009 Tenure in REDD: startpoint or afterthought? International Institute for Environment and Development, London.

Engle, S., Pagiola, S. and Wunder, S. 2008. Designing payments for environmental services in theory and practice: An overview of the issues. Ecological Economics 65(4): 663-674.

Ferguson, B. 2009 REDD in Madagascar: An overview of progress. See: Springate-Baginski, O. and Wollenberg, E. (eds) 2009.

Grieg-Gran, M., Porras, l. and Wunder, S. 2005 How can market mechanisms for forest environmental services help the poor? Preliminary lessons from Latin America. World Development 33 (2005), pp. 1511-1527.

Griffiths, T. and Martone, F. (contributor) 2009 Seeing 'REDD'? forests, climate change mitigation and 
the rights of indigenous peoples. Updated version May 2009. Forest Peoples Programme, Moreton-inMarsh, United Kingdom.

Karsenty, A. 2008 The architecture of proposed REDD schemes after Bali: facing critical choices. International Forest Policy Review 10 (3), 2008.

Kosoy, N., Corbera, E. and Brown, K. 2008 Participation in payments for ecosystem services: Case studies from the Lacandon rainforest, Mexico. Geoforum 39(6): 2073-2083.

Lovera, S. 2008 The hottest REDD issues: rights, equity, development, deforestation and governance by indigenous peoples and local communities. Briefing note, IUCN. www.rightsandresources.org/ publication_details.php?publicationID $=904$.

Malimbwi, R.E. and Zahabu, E. 2009 REDD in Tanzania: Aspects of the National Framework. Workshop proceedings, See: Springate-Baginski, O. and Wollenberg, E. (eds) 2009.

Martin, A. 2009 REDD questions from PES research. In: Springate-Baginski, O. and Wollenberg, E. (eds) 2009.

Nepstad, D., Soares-Filho, B., Merry, F., Moutinho, P., Bowman, M., Schwartzman, S., Almeida, O. and Rivero, S. 2007 REDD: The costs and benefits of reducing carbon emissions from deforestation and forest degradation in the Brazilian Amazon. Woods Hole Research Center, http://www.whrc.org/ resources/published_literature/2006-2007.htm/ (18 November 2009).

Paulsson, E. 2009 A review of the CDM literature: from fine-tuning to critical scrutiny? International Environmental Agreements 9(1): 1567-9764.

Peskett, L., Huberman, D., Bowen-Jones, E., Edwards, G. and Brown, J. 2008 Making REDD work for the poor. Report prepared on behalf of the Poverty Environment Partnership. Overseas Development Institute, London.

Ribot, Jesse C. [forthcoming] Vulnerability does not just fall from the sky: toward multi-scale pro-poor climate policy. In: Robin Mearns and Andrew Norton (eds), Social dimensions of climate change: equity and vulnerability in a warming world. The World Bank, Washington, DC.
Rights and Resources and the Rainforest Foundation Norway. 2008 Foundations for effectiveness: a framework for ensuring effective climate change mitigation and adaptation in forest areas while ensuring human rights and development. www. rightsandresources.org/publication_details. php?publicationID=898.

Robledo, C., Blaser, J., Byrne, S. and Schmidt, K. 2008 Climate change and governance in the forest sector: an overview of the issues on forests and climate change with specific consideration of sector governance, tenure and access for local stakeholders. Rights and Resources Institute, Washington DC.

Salafsky, N. and Wollenberg, E. 2000 Linking livelihoods and conservation: a conceptual framework and scale for assessing the integration of human needs and biodiversity. World Development 28 (8): 1421-38.

Springate-Baginski, O. and Wollenberg, E. (eds) 2009 REDD, forest governance and livelihoods: an emerging agenda. Workshop proceedings 'The Effects of REDD on Local Governance and Livelihoods,' University of East Anglia, Norwich, UK, 6-7 April 2009. CIFOR, Bogor, Indonesia.

Stella Martins, O., Rettmann, R., de Paula, E., Pinto, P., Gabriela Oyo França, F. and Dieguez, R. 2009 REDD: The case of Brazil. See: Springate-Baginski, O. and Wollenberg, E. (eds) 2009.

Wells, M. and Shane, T. 2004 Integrating protected area management with local needs and aspirations. Ambio 33(8): 513-519.

\section{Acknowledgements}

The authors wish to thank Thomas Sikor, Bruce Campbell, the workshop participants, Elena Petkova, CIFOR's reviewers, University of East Anglia, CIFOR and the University of Vermont. The UK Department for International Development provided funding for the workshop. 